\title{
SERIES INDEX
}

This section contains a listing of current working papers by issuing institution. For more complete bibliographic information, consult the entry for the primary author in the author index. Gaps in the listed series may appear either because the paper is not available to AWPE or was not received in time for inclusion. The AWPE Database is available as part of EconLith the American Economic Association's on-line database and CD-ROM. For more information, please contact Cambridge Unversity Press (Call 212/924-3900).

\section{Aarhus Depariment of Economics Working Paper} 1998/05; February 1998. TI Business Cycles and Fiscal Policy in an Open Economy. AU Andersen, Torben M.; Holden, Steinar.

1998/06; March 1998. TI A Note on the Estimation of Markup Pricing in Manufacturing. AU Hylleberg, Svend; Willemoes Joergensen, Rikke.

1998/07; March 1998. TI A Small Country in Europe's Integration. Generalizing the Political Economy of the Danish Case. AU Paldam, Martin.

1998/08; May 1998. TI An Essay on Social Capital. Reflections on a Concept Linking Social Sciences. AU Paldam, Martin; Svendsen, Gert Tinggaard.

1998/09; May 1998. TI Social Insurance and the Public Budget. AU Andersen, Torben M.; Dogonowski, Robert R.

1998/10; June 1998. TI Fiscal Policy Design, Imperfect Competition and Productivity Shocks. AU Dogonowski, Robert R.

1998/1 I; June 1998. TI Should Federal or Regional Insurance Protect the EMU? $\mathbf{\Lambda U}$ Dogonowski, Robert R.

1998/12; June 1998. TI Income Taxation, Imperfect Competition and the Balanced Budget Multiplier. $\Lambda \mathrm{U}$ Dogonowski, Robert R.

1998/13; August 1998. TI EU Enlargement -. Latvia is Ready. AU Yndgaard, Ebbe.

1998/14; September 1998. TI Staggered WageSetting and Output Persistence. AU Andersen, Torben M.

1998/15; September 1998. TI Udviklingslinier i Okonometrien. AU Bunzel, Henning; Christensen, Bent Jesper; Haldrup. Niels; Hylleberg, Svend; Host, Viggo; Jensen, Peter; Wurtz, Allan.

1998/16; September 1998. TI Wage Formation and the (Non-)Existence of the NAIRU. AU Skott, Peter.

1998/18; November 1998. TI Micro-Credit and Group Lending: The Collateral Effect. AU Andersen, Lykke Eg; Nina, Osvaldo.

1998/19; December 1998. TI Sources of Persistence in Employment Adjustment -- Denmark 1974-1993. AU Andersen, Torben M.; Hylleberg, Svend.

1999/01; January 1999. TI Balancing the Budget: Long-Run Adverse Effects of Progressive Taxation.

AU Rasmussen, Bo Sandemann.

1999/02; January 1999. TI Higher Profits and Lower Capital Prices: Is Factor Allocation Optimal? AU Andersen,
Palle Schelde; Klau, Mark; Yndgaard, Ebbe.

1999/03; February 1999. TI Spurious Regression, Cointegration, and Near Cointegration: A Unifying Approach.

AU Haldrup, Niels; Jansson, Michael.

1999/04; April 1999. TI Specifying Nonlinear Econometric Models by Flexible Regression Models and Relative Forecast Performance. AU Dahl, Christian M.; Hylleberg, Svend.

1999/05; April 1999. TI Stability of Functional Rational Expectations Equilibria. AU Kelly, David L.; Shorish, Jamsheed.

1999/06; April 1999. TI Adapting Prices of Quantities in the Presence of Adjustment Costs?

AU Andersen, Torben M.; Toulemonde, Eric.

1999/07; April 1999. TI Imperfectively Competitive Labour Markets and the Productivity Puzzle. AU Andersen, Torben M.; Toulemonde, Eric.

1999/08; May 1999. TI An Investigation of Tests for Linearity and the Accuracy of Flexible Nonlincar Inference.

AU Dahl, Christian M.

1999/09; May 1999. TI The Cost of Ruling. A Foundation Stone for Two Theorics. AU Nannestad, Peter; Paldam, Martin.

1999/10; June 1999. TI Propagation of Nominal Shocks in Open Economics. $\mathbf{A U}$ Andersen. Torben M.; Beier. Nicls C.

1999/11; June 1999. TI The Big Pallem of Corruption. Economics. Culture and the Secsaw Dynamics. AU Paldam, Martin; Beier, Nicls C.

1999/12; June 1999. TI The Location of Firms in Unionized Countries. $\mathbf{\Lambda}$ Munch, Jakob Roland.

1999/13; June 1999. TI Market Forces and Dynamic Asset Pricing. AU Peskir, Goran; Shorish, Jamsheed.

1999/14; Junc 1999. TI Product Market Integration and Wages in Unionized Countries. AU Munch, Jakob Roland; Sorensen, Jan Rose.

1999/15; July 1999. TI The Formation of Inflation Expectations under Changing Inflation Regimes. $\Lambda U$ Dahl, Christian M.; Hansen, Niels L.

1999/16; August 1999. TI Some Reflections on Time and Equilibrium. AU Yndgaard, Ebbe.

1999/17; August 1999. TI Deterring Entry through High Wages. AU Toulemonde, Eric.

1999/18; August 1999. TI On the Equivalence of Taxes Paid by Employers and Employees. $\Lambda \mathrm{U}$ Picard, Pierre 
M.; Toulemonde, Eric.

1999/19; August 1999. TI Wage Bargaining: Reconciling Theory and Evidence. AU Toulemonde, Eric.

1999/20; August 1999. TI Empirically Relevant

Power Comparisons for Limited Dependent Variable Models.

Al) Savin, N. E.; Wurtz, Allan H.

1999/21; September 1999. TI Corruption and Religion. Adding to the Economic Model? AU Paldam, Martin.

\section{Centre for Economic Policy Research, Discussion Paper}

1828; April 1998. TI Staying Afloat When the Wind Shifts: External Factors and Emerging- Market Banking Crises. AU Eichengreen, Barry; Rose, Andrew K.

1829; February 1998. TI Regional Redistribution and Stabilization by the Centre in Canada, France, the United Kingdom and the United States: New Estimates Based on Panel Data Econometrics. AU Melit, Jacques; Zumer, Frederic.

1830; March 1998. TI An Economic Model of Houschold Income Dynamics, With an Application to Poverty Dynamics Among American Women. AU Burgess, Simon; Propper, Carol.

1831; March 1998. TI Notes on "A Code for Fiscal Stability". AU Buiter, Willem H.

1832; April 1998. TI A Quantative Analysis of Swcdish Fertility Dynamics: 1751-1990. AU Eckstcin, Zvi; Mira, Pedro; Wolpin, Kenneth I.

1833; March 1998. TI The Structure of Wages and Investment in Gencral Training. AU Acemuglu, Daron; Pischke, Jorn-Steffen.

1834; March 1998. TI The Risk of Defiation in the Future EMU. Lessons of the 1990's. AU De Grauwe, Paul.

1835: March 1998. TI Enterprise Investment During the Transition: Evidence from Czech Panel Data. AU Lizal, Lubomir; Svcjnar, Jan.

1836; March 1998. TI Fiscal Solvency and Fiscal Forecasting in Europe.' AU Artis, Michael J.; Marcellino, Massimiliano.

1837; March 1998. TI Channelling Domestic Savings into Productive Investment Under Asymmetric Information: The Essential Role of Foreign Direct Investment. AU Razin, Assaf; Sadka, Efraim; Yuen, Chi-Wa.

1838; March 1998. TI From Federalism, Chinese Style, to Privatization, Chinese Style. AU Cao, Yuanzheng; Qian, Yingyi; Weingast, Barry R.

1839; March 1998. TI How Efficient are Firms in Transition Countries? Firm-Level Evidence from Bulgaria and Romania. AU Konings, Jozef; Repkin, Alexander.

1840; March 1998. TI Unemployment Duration, Benefit Duration and the Business Cycle. AU Bover, Olympia; Arellano, Manuel; Bentolila, Samuel.

1841; March 1998. TI Public Policies, Regional Inequalities and Growth. AU Martin, Philippe.

1842; March 1998. TI Independently Blue? Accountability and Independence in the New European Central Bank. AU Demertzis, Maria; Hallett, Andrew Hughes; Viegi, Nicola.

1843; March 1998. TI Large Scale Fiscal
Retrenchments: Long-Run Lessons from the Stability Pact. AU Hallett, Andrew Hughes; McAdam, Peter.

1844; March 1998. TI Privatization, Efficiency and Economic Growth. AU Gylfason. Thorvaldur.

1845; March 1998. TI Agglomeration and Endogenous Capital. AU Baldwin, Richard E.

1846; March 1998. TI Bankers' Versus Workers' Europe (I): Adverse Selection in EMU. AU Bottazzi, Laura; Manasse, Paolo.

1847; March 1998. TI Central Bank Independence, Centralization of Wage Bargaining, Inflation and Unemployment -- Theory and Evidence. AU Cukierman, Alex; Lippi, Francesco.

1848; March 1998. TI Endogenous Tariff Formation: The Case of MERCOSUR. AU Olarreaga, Marcelo; Soloaga Isidro.

1849; March 1998. TI Sticky Prices and Volatile Outpul: Or When is a Phillips Curve not a Phillips Curve. AU Ellison, Martin; Scott, Andrew.

1850; March 1998. TI Enforcement of Employment Security Regulations, On-the-Job Search and Unemployment Duration. AU Boeri, Tito.

1851: March 1998. TI Multiproduct Multinationals and Reciprocal FDI Dumping. $\mathbf{\Lambda U}$ Baldwin, Richard E.; Ottaviano, Gianmarco I. P.

1852; March 1998. TI Transparency and Credibility: Monctary Policy with Unobservable Goals. AU Faust, Jon; Svensson, Lars E. O.

1853: March 1998. TI The Absorption of HighlySkilled Immigrants: Isracl, 1990-95. AU Eckstein, Zvi; Weiss, Yoram.

1854; April 1998. TI Extcrnaljites in the Matching of Workers and Firms in Britain. $\Lambda U$ Burgess. Simon; Profit, Stefan.

1855; April 1998. TI Innovation and Growth with Rich and Poor Consumers. AU Zweimuller, Josef; Brunner, Johann $\mathrm{K}$.

1856; April 1998. TI Learning for Employment. Innovating for Growth. $\Lambda \mathrm{U}$ Falkinger, Josef; Zweimuller, Josef.

1857; April 1998. TI Economic Geography, Comparative Advantage and Trade Within Industries: Evidence from the OECD. $\mathbf{A U}$ Greenaway, David; Torstensson, Johan.

1858; April 1998. TI Ruling Out Indeterminacy: The Role of Heterogeneity. AU Herrendorf, Berthold; Valentinyi, Akos.

1859; April 1998. TI Discrimination and Skill Differences in an Equilibrium Search Model. AU Bowlus, Audra J.; Eckstein, Zvi.

1860; April 1998. TI Union Wage Bargaining and European Antidumping Policy in Imperfectly Competitive Markets. AU Konings, Jozef; Vandenbussche, Hylke.

1861; April 1998. TI Youth Employment and Academic Performance in High School. AU Eckstein, Zvi; Wolpin, Kenneth I.

1862; April 1998. TI An Applied Econometrician's View of Large Company Performance. AU Geroski, Paul A.

1863; April 1998. TI "Globalization" and Relocation in a Vertically Differentiated Industry. AU Cordella, Tito; 
Grilo, Isabel.

1864; April 1998. TI Interventions Versus Customer Transactions: An Alternative Test of the Signalling Hypothesis. AU Fischer, Andreas M.; Zurlinden, Mathias.

1865: April 1998. TI Does PPP-Adjusted Data Exaggerate the Relative Size of Poor Economies. AU Honohan, Patrick.

1866; April 1998. TI Asset Bubbles, Domino Effects

and 'Lifeboats': Elements of the East Asian Crisis.

AU Edison, Hali J.; Luangaram, Pongsak.

1867; April 1998. TI Agglomeration Economies, Technology Spillovers and Company Productivity Growth. AU Geroski, Paul A.; Walters, Chris F.

1868; June 1998. TI Block Premia in Transfers of Corporate Control. AU Burkart, Mike; Gromb, Denis; Panunzi, Fausto.

1869; May 1998. TI Wages and Worker Displacement in Germany. AU Burda, Michael C.; Mertens, Antje.

1870; April 1998. TI Local Unemployment and Specialization. AU Ritter, Peer; Walz, Uwe.

1871; April 1998. TI European Integration and the Future of the Welfare State. AU Sinn, Hans-Wemer.

1872; April 1998. TI Stability Without a Pact? Lessons from the European Gold Standard 1880-1914. AU Flandreau, Marc; Le Cacheux, Jacqucs; Zumer, Frederic.

1873; April 1998. TI Headline Underpricing and Entrepreneurial Wealth Losscs in IPO's: Theory and Evidence. IU Habib, Michel A.; Ljungqvist, Alexander P.

1874; Junc 1998. TI Economic Policy and Reforms in Contemporary Italy. AU Schioppa Kostoris, Fiorella Padoa.

1875; May 1998. TI Recurrent Hyperinflations and Learning. AU Marcet, Albert; Nicolini, Juan Pablo.

1876; November 1998. TI Immigrant Labour and Workplace Safety. AU Bauer, Thomas; Zimmermann, Klaus; Million, Andreas; Rotte, Ralph.

1877; May 1998. TI Determinants of Atutudes Towards Immigration: A Trade-Theoretic Approach. AU Bilal, Sanoussi; Grether, Jean-Maric; de Melo, Jaime.

1878; May 1998. TII Can Bilateralism Ease the Pains of Multilateral Trade Liberalization? AU Cadot, Olivier; de Melo, Jaime; Olarreaga, Marcelo.

1879; June 1998. TI Does Training Generally Work? The Returns to In-Company Training. AU Barrett, Alan; O'Connell, Philip J.

1880; May 1998. TI Schumpeterian Entrepreneurs Meet Engel's Law: The Impact of Inequality on InnovationDriven Growth. AU Zweimuller, Josef.

1881; May 1998. TI The Consequences of EU Enlargement for Central and Eastem European Labour Markets. AU Burda, Michael C.

1882; May 1998. TI An Egypt-United States Free Trade Agreement: Economic Incentives and Effects. AU Hoekman, Bemard; Konan, Denise; Maskus, Keith.

1883; May 1998. TI Avenues of Technology Transfer: Foreign Investment and Productivity Change in the Czech Republic. AU Djankov, Simeon; Hoekman, Bemard.

1884; May 1998. TI Inspecting the Mechanism: The
Determination of Asset Prices in the Real Business Cycle Model. AU Lettau, Martin.

1885; May 1998. TI Performance Measures for Dynamic Portfolio Management. AU Vassalou, Maria; Nielson, Lars Tyge.

1886; May 1998. TI Public Disclosure and Bank Failures. AU Cordella, Tito; Yeyati, Eduardo Levy.

1887; July 1998. TI Venture Capital: A Case for Investment Promotion. AU Keuschnigg, Christian.

1888; May 1998. TI Project Evaluation and Organizational Form. AU Gehrig, Thomas; Regibeau, Pierre; Rockett, Kate.

1889; May 1998. TI Capital Flows to Emerging Markets: Liberalization, Overshooting and Volatility. AU Bacchetta, Philippe; Van Wincoop, Eric.

1890; May 1998. TI Spurious Correlation in Exchange Rate Target Zone Modelling: Testing the Drift Adjustment Method on the US Dollar, Random Walk and Chaos. AU Darvas, Zsolt M.

1891; May 1998. TI Expropriation and Control Rights: A Dynamic Model of Foreign Direct Investment. AU Schnitzer, Monika.

1892; May 1998. TI Does the Term Structure Predict Recessions? The International Evidence. AU Gerlach, Stefan; Bemard, Henri.

1893; June 1998. TI Measuring Risk Attitudes in a Natural Experiment: Data from the Television Game Show LINGO. AU Beetsma, Rocl M. W. J.; Schotman, Petcr C.

1894; June 1998. TI Cities and the Geography of Financial Centres. AU Gchrig, Thomas.

1895; June 1998. TI The Long-Run Educational Cosi of World War II: An Example of Local Average Treatment Effect Estimation. AU Ichino, Andrea; Winter-Ebmer, Rudolf.

1896; May 1998. TI The Impact of Exchange Rate Uncertainty on the Level of Investment. AU Hughes Hallett, Andrew J.; Darby, Julia; Ireland, Jonathon; Piscitclli, Laura.

1897; June 1998. TI A Gini Decomposition Analysis of Inequality in the Czech and Slovak Republics During the Transition. AU Gamer, Thesia I.; Terrell, Kacherine.

1898; June 1998. TI Currency Crisis and Unemployment: Sterling in 1931. AU Eichengreen, Barry; Jeanne, Olivier.

1899; May 1998. TI Fiscal Discipline and Exchange Rate Regimes. AU Canzoneri, Matthew B.; Diba, Behzad T.; Cumby, Robert E.

1900; June 1998. TI Ownership and Growth. AU Gylfason, Thorvaldur; Zoega, Gylfi; Herbertsson, Tryggvi Thor.

1901; June 1998. TI Technology in Growth. AU Quah, Danny T.; Keely, Louise C.

1902; June 1998. TI A Bargaining Model of Farrell Inefficiency. AU Haskel, Jonathan; Sanchis, Amparo.

1903; June 1998. TI Agglomeration and Trade Revisited. AU Ottaviano, Gianmarco I. P.; Thisse, JacquesFrancois.

1904; June 1998. TI The Extemal Sector, the State and Development in Eastern Europe. AU Eichengreen, Barry; Kohl, Richard. 
1905; June 1998. TI Price Competition Between an Expert and a Non-Expert. AU Degryse, Hans; Bouckaert, Jan.

1906; June 1998. TI Monetary Policy and Credit in China: A Theoretical Analysis. AU Bennett, John; Dixon, Huw David.

1907; June 1998. TI Computers and the Demand for Skilled Labour: Industry and Establishment-Level Panel Evidence for the United Kingdom. AU Haskel, Jonathan; Hecien, Ylva.

1908; June 1998. TI Monetary Policy Rules and Macroeconomic Stability: Evidence and Some Theory. AU Clarida, Richard; Gali, Jordi; Gertler, Mark.

1909; June 1998. TI Workers' Versus Bankers' Europe (II): Policy Externalities and Credibility in EMU. AU Manasse, Paolo; Bottazzi, Laura.

1910; June 1998. TI Contentious Contracts. AU Hege, Ulrich; Viala, Pascale.

1911; June 1998. TI Labour Force Transitions of Older Married Couples in Germany. AU Riphahn, Regina T.; Blau, David M.

1912; Junc 1998. TI Union Power and Product Market Competition: Evidence from the Airline Industry. AU Neven, Damien J.: Roller, Lars-Hendrik; Zhang, Zhentang.

1913; July 1998. TI Education and Borrowing Constraints: Tests vs. Prices. AU Femandez, Raquel.

1914; July 1998. TI Demand Uncertainty, Mismatch and (Un)Employment: A Microeconomic Approach. AU Thissc, Jacques-Francois; Zenou, Yves; Jellal, Mohamed.

1915: Junc 1998. TI Estimating Labour Market Discrimination with Sclectivity Corrected Wage Equations: Methodological Considerations and an Illustration from Israel. AU Ncuman, Shoshana; Oaxaca, Ronald L.

1916; Junc 1998. TI Beat 'Em or Join 'Em?: Export Subsidics Versus Intemational Research Joint Ventures in Oligopolistic Markets. AU Neary, I. Peter; O'Sullivan, Paul.

1917; June 1998. TI Lending Relationships in Germany: Empirical Results from Survey Data. AU Harhoff, Dietmar; Korting, Timm.

1918; June 1998. TI Banking (Conscrvatively) With Optimists. AU Padilla, A. Jorge; Manove, Michael.

1919; July 1998. TI Trade, Technology and Wages: General Equilibrium Mechanics. AU Francois, Joseph F.; Nelson, Douglas.

1920; July 1998. TI Determinants of International Migration: Empirical Evidence for Migration from Developing Countries to Germany. AU Rotte, Ralph; Vogler, Michael.

1921; July 1998. TI Current Account Reversals and Currency Crises: Empirical Regularities. AU Razin, Assaf; Milesi-Fcrretti, Gian Maria.

1922; July 1998. TI Strategic Pricing and Entry under Universal Service and Cross-Market Price Constraints. AU Anton, James J.; Vander Weide, James H.; Vettas, Nikolaos.

1923; August 1998. TI Dispersion and Volatility in Stock Retums: An Empirical Investigation. AU Lettau, Martin; Campbell, John Y; Kim, Sangjoon.

1924; July 1998. TI What Kind of Regional
Convergence? AU de la Fuente, Angel.

1925; July 1998. TI The Evolution of Modern Educational Systems: Technical Vs. General Education, Distributional Conflict and Growth. AU Bertocchi, Graziella; Spagat, Michael.

1926; July 1998. TI Trade and the Number of Optimum Currency Areas in the World. AU Artis, Michael J.; Melitz, Jacques; Kohler, Marion.

1927; July 1998. TI The Demand for Money, Financial Innovation and the Welfare Cost of Inflation: An Analysis with Households' Data. AU Attanasio, Orazio P.; Guiso, Luigi; Jappelli, Tullio.

\section{International Monetary Fund Working Paper}

WP/98/45; April 1998. TI Output Decline in Transition: The Case of Kazakhstan. AU De Broeck, Mark; Kostial, Kristina.

WP/98/46; April 1998. TI The Relative Importance of Political and Economic Variables in Creditworthiness Ratings. AU Haque, Nadeem U.; Mark, Nelson; Mathieson, Donald J.

WP/98/47; April 1998. TI Immigration Flows and Regional Labor Market Dynamics. AU Gross, Dominique M. WP/98/48; April 1998. TI "Globalization" and Relocation in a Vertically Differentiated Industry. nU Cordella, Tito; Grilo, Isabel.

WP/98/49; April 1998. TI Trade Liberalization and

Tax Reform in the Southem Mcditcranean Region. $\Lambda \mathbf{U}$ Abed, Gcorge T.

WP/98/50; April 1998. TI EMU, Adjustments, and Exchange Rate Variability. AU Ricci, Luca Antonio; Isard, Peter.

WP/98/51; April 1998. TI The Canadian Agreement on Internal Trade: Devclopments and Prospects. $\Lambda \mathrm{U}$ Leidy, Michael P.

WP/98/52; April 1998. Tl From Transition to Market: Evidence and Growth Prospects. $\Lambda U$ Fischer, Stanley; Sahay, Ralna; Vegh, Carlos A.

WP/98/53; April 1998. TI How Far is Eastern Europe from Brussels? $\Lambda U$ Fischer, Stanley; Sahay, Ratna; Vegh, Carlos A.

WP/98/54; March 1998. TI The Design of Instruments for Government Finance in an Islamic Economy. AU Haque, Nadeem U.; Mirakhor, Abbas.

WP/98/55; April 1998. TI Fiscal Discipline and the Cost of Public Debt Service: Some Estimates for OECD Countries. AU Caselli, Francesco; Giovannini, Alberto; Lane, Timothy.

WP/98/56; April 1998. TI Public Sector Efficiency and Fiscal Austerity. AU Haque, Nadeem U.; Montiel, Peter J.; Sheppard, Stephen.

WP/98/57; April 1998. TI Money Demand and Regional Monetary Policy in the West African Economic and Monetary Union. AU Rother, Philipp C.

WP/98/58; April 1998. TI Competitiveness and the Evolution of the Real Exchange Rate in Chile. AU Guerguil, Martine; Kaufman, Martin.

WP/98/59; April 1998. TI Interest Rate Spreads in the Eastem Caribbean. AU Randall, Ruby. 
WP/98/60; April 1998. TI Growth, Trade, and Deindustrialization. AU Rowthom, Robert; Ramaswamy, Ramana.

WP/98/61; April 1998. TI Rethinking Public Pension Reform Initiatives. AU Heller, Peter S.

WP/98;62; April 1998. TI Multiple Equilibrium, Variability, and the Development Process. AU Carranza, Luis; Galdon-Sanchez, Jose E.

WP/98/63; May 1998. TI Corruption Around the World: Causes, Consequences, Scope, and Cures. AU Tanzi, Vito.

WP/98/64; May 1998. TII The Domestic and Foreign Price Gaps in the P-Star Model: Evidence from Spain. AU Garcia-Herrero, Alicia; Pradhan, Manoj Vasant.

WP/98/65; May 1998. TI Central Bank Vulnerability and the Credibility of Commitments: A Value-at-Risk Approach to Currency Crises. AU Blejer, Mario I.; Schumacher, Liliana.

WP/98/66; May 1998. TI The Fiscal Effects of Monetary Policy. $\mathrm{AU}$ Dahan, Momi.

WP/98/67; May 1998. TI Exchange Rates and Economic Fundamentals: A Methodological Comparison of BEERs and FEERs. AU Clark, Peter B.; MacDonald, Ronald.

WP/98/68; May 1998. TI Inflation, Disinflation, and Growth. AU Ghosh, Atish R.; Phillips, Steven.

WP/98/69; May 1998. TI Deviations of Exchange Rates from Purchasing Power Parity: A Story Featuring Two Monctary Unions. AU Bayoumi, Tamim; MacDonald, Ronald.

WP/98/70; May 1998. TI Government Expenditure Arrears: Securitization and Other Solutions. $\mathbf{\Lambda U}$ Ramos, Alberto $\mathrm{M}$.

WP/98/71; May 1998. TI Current Accounts: What is Their Relevance for Economic Policymaking? AU Knight, Malcolm; Scacciavillani, Fabio.

WP/98/72; May 1998. TI Extemal Debt Histories of the Ten Low-Income Developing Countries: Lessons from Their Experience. AU Brooks, Ray; Cortes, Mariano; Fomessari, Francesca; Kctchekmen, Benoit; Metzgen, Ydahlia; Powell, Robert: Rizabi, Saqib; Ross, Doris; Ross, Kevin.

WP/98/73; May 1998. TI Carbon Taxes: Their Macroeconomic Effects and Prospects for Global Adoption -- A Survey of the Literature. AU Cuervo, Javier; Gandhi, Ved P.

WP/98/74; May 1998. TI The Italian Social Protection System: The Poverty of Welfare. AU Rostagno, Massimo V.; Utili, Francesca.

WP/98/75; May 1998. TI The Macroeconomic Effects of Environmental Taxes: A Closer Look at the Feasibility of "Win-Win" Outcomes. AU Ligthart, Jenny E.

WP/98/76; May 1998. TI Does Comption Affect Income Inequality and Poverty? AU Gupta, Sanjeev; Davoodi, Hamid; Alonsa-Terme, Rosa.

WP/98/77; May 1998. TI How Do the Skilled and the Unskilled Respond to Regional Shocks? The Case of Spain. AU Mauro, Paolo; Spilimbergo, Antonio.

WP/98/78; May 1998. TI Reducing Inflation: Lessons from Albania's Early Success. AU McNeilly, Caryl J.; Schiesser-Gachnang, Doris.

WP/98/79; May 1998. TI Responses of the Stock
Market to Macroeconomic Announcements Across Economic States. AU ' $\mathrm{Li}, \mathrm{Li}$; $\mathrm{Hu}, \mathrm{Zuliu} F$.

WP/98/80; June 1998. TI A Model for Financial Programming. AU Mikkelsen, Jan G.

WP/98/81; June 1998. TI Exchange and Capital Controls as Barriers to Trade. AU Tamirisa, Natalia T.

WP/98/82; June 1998. TI Selected Transition and Mediterranean Countries: An Institutional Primer on EMU and EU Relations. AU Temprano-Arroyo, Heliodoro; Feldman, Robert A.

WP/98/83; June 1998. TI Financial Liberalization and Financial Fragility. AU Demirguc-Kunt, Asli; Detragiache, Enrica.

WP/98/84; June 1998. TI Trading Blocs and Welfare:

How Trading Bloc Members Are Affected by New Entrants. AU Hacker, Scott; Hussain, Qaizar.

WP/98/85; June 1998. TI The Effects of European Economic Integration on the Profitability of Industries AU Hakura, Dalia S.

WP/98/86; June 1998. TI Japanese Effective Exchange Rates and Determinants: Prices, Real Interest Rates, and Actual and Optimal Current Accounts. AU Nagayasu, Jun.

WP/98/87; June 1998. TI The United Kingdom's Experience with Inflation Targeting. $\mathbf{\Lambda} \mathbf{U}$ Lanc, Timothy; van den Heuvel, Skander.

WP/98/88; June 1998. TI The Price Incentive To Smuggle and the Cocoa Supply in Ghana, 1950-96. AU Bulir, Ales.

WP/98/89; June 1998. TI Current Account Reversals and Currency Crises: Empirical Regularities. AU MilesiFerretti, Gian Maria; Razin, Assaf.

WP/98/90; June 1998. TI Intermediation Sprcads in a Dual Currency Economy: Argentina in the 1990s. AU Catao, Luis.

WP/98/91; June 1998. TI Lcading Indicators of Banking Crises: Was Asia Different? AU Hardy, Daniel C.; Pazarbasioglu, Ceyla.

WP/98/92; June 1998. TI Asymmetric Information and the Market Structure of the Banking Industry. AU Ariccia, Giovanni Dell.

WP/98/93; June 1998. TI Bank Lending and Interest Rate Changes in a Dynamic Matching Model. AU Ariccia, Giovanni Dell; Garibaldi, Pietro.

WP/98/94; June 1998. TI North-South Trade: Is Africa Unusual? AU Coe, David T.; Hoffmaister, Alexander W.

WP/98/95; June 1998. TI Liberating Supply: Fiscal Policy and Technological Innovation in a Multicountry Model. AU Bayoumi, Tamim; Coe, David T.; Laxton, Douglas.

WP/98/96; June 1998. TI Banking System Restructuring in Kazakhstan. AU Hoelscher, David S.

WP/98/97; June 1998. TI Financial Opening, Dcposit Insurance, and Risk in a Model of Banking Competition. AU Cordella, Tito; Yeyati, Eduardo Levy.

WP/98/98; July 1998. TI The Impact of Economic Security on Bank Deposits and Investment. AU Fabricius, Michael.

WP/98/99; July 1998. TI Explaining Investment in 
the WAEMU. AU Vamrakidis, Athanasios.

WP/98/100; July 1998. TI From Inflation to Growth: Eight Years of Transition. AU Christoffersen, Peter; Doyle, Peter.

WP/98/101; July 1998. TI Inflation and Money Demand in Albania. AU Kalra, Sanjay.

WP/98/102; July 1998. TI How Big is the Brain Drain? AU Carrington, William J.; Detragiache, Enrica.

WP/98/103; July 1998. TI Policy Responses to External Imbalances in Emerging Market Economies -- Further Empirical Results. AU Wong, Chomg-Huey; Carranza, Luis. WP/98/104; July 1998. TI Determinants of Growth in an Error-Correction Model for El Salvador. AU Morales, R. Armando.

WP/98/105: July 1998. TI Developing Countries and the Globalization of Financial Markets. AU Knight, Malcolm.

WP/98/106; August 1998. TI Disinflation in Spain: The Recent Experience. AU Sobczak, Nicolas.

WP/98/107; August 1998. TI Exchange Rate Fluctuations and Trade Flows: Evidence from the European Union. $\Lambda U$ Ariccia, Giovanni Dell.

WP/98/108; August 1998. TI Structural Reforms in Government Bond Markets. $\Lambda U$ De Broeck, Mark; Guillaume, Dominique; yau der Stichele, Emmanuel.

WP/98/109; August 1998. TI Considerations in Reducing Inflation from Low to Lower Levels. $\Lambda \mathrm{U}$ Lcidy. Michacl P.; Tokarick, Stcphen.

WP/98/110; August 1998. TI Interest Spreads in Banking: Costs, Financial Taxation, Market Power, and Loan Quality in the Colombian Case 1974-96. AU Barajas, Adolfo; Stciner, Roberto; Salazar, Natalia.

WP/98/111; August 1998. TI Welfare Cost of (Low) Inflation: A General Equilibrium Perspective. $\mathbf{\Lambda U} Z \mathbf{Z c e}$ Howell H.

WP/98/112; August 1998. TI Liability-Crcating Versus Non-Liability-Creating Fiscal Stabilization Policies: Ricardian Equivalence, Fiscal Stabilization, and EMU. AU Bayoumi, Tamim; Masson, Paul R.

WP/98/112; August 1998. TI Tax Smoothing in a Financially Repressed Economy: Evidence from India. AU Cashin, Paul; Olekalns, Nilss; Sahay, Ratna.

WP/98/113; August 1998. TI Market-Based Policy Instruments for Systematic Bank Restructuring. AU Dziobek, Claudia.

WP/98/114; August 1998. TI The Transmission of Monetary Policy in Israel. AU De Fiore, Fiorella.

WP/98/115; August 1998. TI Consequences of the Economic and Monetary Union for the Coordination of Tax Systems in the European Union: Lessons from the U.S. Experience. $\Lambda U$ Tanzi, Vito; Zee, Howell H.

WP/98/116; August 1998. TI Impact of European Union Association Agreements on Mediterranean Countries.

AU Ghesquiere, Henri.

WP/98/117; August 1998. TI Deviations From Uncovered Interest Parity: A Global Guide to Where the Action Is. AU Tanner, Evan.

WP/98/118; August 1998. TI Macroeconomic Performance Under Altemative Exchange Rate Regimes: Does
Wage Indexation Matter? AU Jadresic, Esteban. WP/98/119; August 1998. TI Search Unemployment with Advance Notice. AU Garibaldi, Pietro.

WP/98/120; August 1998. TI The Demise of the Nation State? AU Tanzi, Vito.

WP/98/121; August 1998. TI Capital Structures and Portfolio Composition During Banking Crisis: Lessons from Argentina 1995. AU Ramos, Alberto M.

WP/98/123; August 1998. TI Does the Long-Run PPP Hypothesis Hold for Africa?: Evidence from Panel CoIntegration Study. AU Nagayasu, Jun.

WP/98/124; August 1998. TI Self-Fulfilling Risk Predictions: An Application to Speculative Attacks. AU Flood, Robert P.; Marion, Nancy P.

WP/98/125; August 1998. TI Fixed Investment and Capital Flows: A Real Options Approach. AU Chan-Lau, Jorge A.; Clark, Peter B.

WP/98/126; August 1998. TI Central Banking in Transition Countries. AU Wagner, Helmut.

WP/98/127; August 1998. TI Financial Crisis and Credit Crunch as a Result of Inefficient Financial Intermediation -- with Reference to the Asian Financial Crisis. AU Chan-Lau, Jorge A.; Chen, Zhaohui.

WP/98/128; August 1998. TI The East Asian Crisis: Macroeconomic Developments and Policy Lessons. AU Kochhar, Kalpana; Loungani, Prakash; Stone, Mark R.

WP/98/129; September 1998. TI Increasing Dependency Ratios, Pensions, and Tax Smoothing.

AU Sadka, Efriam; Tanzi, Vito.

WP/98/130; Scptember 1998. TI Perspectives on the Recent Currency Crisis Litcraturc. $\mathbf{\Lambda}$ Flood, Robert P.; Marion, Nancy $P$

WP/98/131; Scptember 1998. TI Can Short-Term Capital Controls Promote Capital Inflows? $\mathbf{\Lambda} \mathbf{U}$ Cordella, Tito.

WP/98/132; September 1998. TI Output Decline and Recovery in Uzbekistan: Past Performance and Future Prospects. AU Taube, Gunther; Zeltelmeyer, Jcromin.

WP/98/133; Septcmber 1998. TI The Uzbck Growth Puzzle. AU Zettelmeyer, Jeromin.

WP/98/134; September 1998. TI The Role of Allocation in a Globalized Corporate Income Tax. AU Mintz, Jack $M$.

WP/98/135; September 1998. TI Tax Revenue in Sub-Saharan Africa: Effects of Economic Policies and Corruption. AU Ghura, Dhaneshwar.

WP/98/136; September 1998. TI Is the United States CPI Biased Across Income and Age Groups? AU Erbas, S. Nuri; Sayers, Chera $L$.

WP/98/137; September 1998. T1 East Asian Growth Before and After the Crisis. AU Crafts, Nicholas.

WP/98/138; September 1998. TI Managing Corporate Distress in the Philippines: Some Policy Recommendations. AU Lim, Cheng Hoon; Woodruff, Charles.

WP/98/139; September 1998. TI Can the Neoclassical Model Explain the Distribution of Foreign Direct Investment Across Developing Countries? AU Zebregs, Harm. 
WP/98/140; September 1998. TI From Autarky to Integration: Imitation, Foreign Borrowing, and Growth. AU van Elkan, Rachel.

WP/98/141; September 1998. TII Recovery and Growth in Transition Economies 1990-97: A Stylized Regrcssion Analysis. AU Havrylyshyn, Oleh; Izvorski, Ivailo; van Rooden, Ron.

WP/98/142; September 1998. TI Contagion: Monsoonal Effects, Spillovers, and Jumps Between Multiple Equilibria. AU Masson, Paul R.

WP/98/143; September 1998. TI Crises, Contagion, and the Closed-End Country Fund Puzzle. AU Levy-Yeyati, Eduardo; Ubide, Angel.

WP/98/144; September 1998. TI Monetary Operations and Government Debt Management Under Islamic Banking. AU Sundararajan, V.; Marston, David; Shabsigh, Ghiath.

Monash Department of Econometrics and Business Statistics Working Papers

01/99; January 1999. TI Forecasting Models and Prediction Intervals for the Multiplicative Holt-Winters Mcthod. AU Koehler, Anne B.; Snyder, Ralph D.; Ord, J. Keith.

02/99; January 1999. TI Generalized Additive Modelling of Mixed Distribution Markov Models With Application to Melboume's Rainfall. AU Hyndman, Rob J.: Grunwald, Gary K.

03/99; March 1999. TI School-Leavers' Transition to Tertiary Study: A Literature Review. AU Evans, Merran.

04/99; March 1999. TI The Predictive Approach to Teaching Statistics. AU McLean, Alan.

05/99; March 1999. TI Inter-Regional Migration in Australia: An Applied Economic Analysis. AU Fry, Jane; Fry, Tim R. L.; Peter, Matthew W.

06/99; March 1999. TI Estimating Advertising HalfLife and the Data Interval Bias. AU Fry, Tim R. L.; Broadbent, Simon; Dixon, Janine M.

07/99; June 1999. TII Forecasting Sales of Slow and Fast Moving Inventories. AU Snyder, Ralph D.

08/99; June 1999. TI Does International Trade Synchronize Business Cycles? AU Anderson, Heather M.; Kwark, Noh-Sun; Vahid, Farshid.

09/99; June 1999. TI Forecasting Time Series From

Clusters. AU Maharaj, Elizabeth A.; Inder, Brett.

12/98; September 1998. TI Residual Diagnostic Plots For Checking For Model Mis-Specification In Time Series Regression. AU Fraccaro, Richard; Hyndman, Rob J.; Veevers, Alan.

13/98; October 1998. TI Lead Time Demand for Simple Exponential Smoothing. AUU Snyder, Ralph D.; Koehler, Anne B.; Ord, J. Keith.

14/98; October 1998. TI Testing Convergence in Economic Growth for OECD Countries. AU Nahar, Syfun; Inder, Brett.

15/98; October 1998. TI Model Selection When a Key Parameter is Constrained to be in an Interval.

AU Hossain, Zakir; King, Maxwell L.

16/98: October 1998. TI Bandwidth Selection for
Kemel Conditional Density Estimation. AU Bashtannyk, David M.; Hyndman, Rob J.

17/98; December 1998. TI Nonparametric Estimation and Symmetry Tests for Conditional Density Functions. AU Hyndman, Rob J.; Qiwei Yao.

18/98; December 1998. TI Institutional Characteristics and the Relationship Between Students' FirstYear University and Final-Year Secondary School Academic Performance. AU Evans, Merran; Farley, Alan.

\section{National Bureau of Economic Research Working Paper}

6177; September 1997. TI Implicit Contracts and the Theory of the Firm. AU Baker, George; Gibbons, Robert; Murphy, Kevin J.

6178; September 1997. TI Retirement Wealth Accumulation and Decumulation: New Developments and Outstanding Opportunities. AU Mitchell, Olivia S.; Moore, James $\mathrm{F}$.

6179; September 1997. TI Implied Exchange Ratc Distributions: Evidence from OTC Option Markets. AU Campa, Jose M.; Chang, P. H. Kevin; Reider, Robert L.

6180; September 1997. TI Gcographical and Scctoral Shocks in the U.S. Business Cycle. $\Lambda U$ Ghosh, Atish R.; Wolf, Holger $\mathrm{C}$.

6181; September 1997. TI Revenue Neutral Trade Reform with Many Houscholds, Quotas and Tariffs. $\mathrm{AU}$ Anderson, James E.

6182; September 1997. TI Is Price Inflation Different for the Elderly? An Empirical Analysis of Prescription Drugs. AU Berndh, Emst R.; Cockbum, Iain M.; Cocks, Douglas L.; Epstein, Amold; Griliches, Zvi.

6183; September 1997. TI Efficient Inflation Estimation. AU Bryan, Michael F.; Cecchelti, Stephen G.; Wiggins, Rodney L., II.

6184; September 1997. TI Procompetitive Markct Access. $\Lambda \mathbb{U}$ Krishna, Kala; Roy, Suddhasalwa: Thursby, Marie.

6185; September 1997. TI Houschold Portfolio Allocation Over the Life Cycle. AU Poterba, James M.; Samwick, Andrcw A.

6186; Scptember 1997. TI Anonymous Market and Group Ties in International Trade. AU Casella, Alessandra; Rauch, James E.

6187; September 1997. TI Managed Care and Health Care Expenditures: Evidence from Medicare, 1990-1994. AU Baker, Laurence C.; Shankarkumar, Sharmila.

6188; September 1997. TI Doing Without Money: Controlling Inflation in a Post-Monetary World. AU Woodford, Michael.

6189; September 1997. TI Capital Income Taxation and Risk-Taking in a Small Open Economy. $\Lambda \mathbf{U}$ Asea, Patrick K.; Tumovsky, Stephen J.

6190; September 1997. TI Entry Decisions in the Generic Pharmaceutical Industry. AU Scott Morton, Fiona M.

6191; September 1997. TI Juvenile Crime and Punishment. AU Levitt, Steven D.

6192; September 1997. TI Investment Tax Incentives, 
Prices, and the Supply of Capital Goods. AU Goolsbee, Austan.

6193; September 1997. TI The Predictive Validity of Subjective Probabilities of Survival. AU Hurd, Michael D.; McGarry, Kathleen.

6194; September 1997. TI Adverse Selection in Durable Goods Markets. AU Hendel, Igal; Lizzeri, Alessandro.

6195; September 1997. TI Immigration and the Quality of Jobs. AU Hamermesh, Daniel S.

6196; September 1997. TI Restraining the Leviathan: Property Tax Limitation in Massachusetts. AU Cutler, David M.; Elmendorf, Douglas W.; Zeckhauser, Richard J.

6197; September 1997. TI Optimal Management of Indexed and Nominal Debt. AU Barro, Robert J.

6198; September 1997. TI Schooling Quality in a Cross Section of Countries. AU Lee, Jong-Wha; Barro, Robert J.

6199; September 1997. TI Environmental Taxes and the Double-Dividend Hypothesis: Did You Really Expect Somcthing for Nothing? AU Fullerton, Don; Metcalf, Gilbert E.

6200; September 1997. TI Capital Income Taxes and the Benefit of Price Stability. $\Lambda U$ Feldsicin, Martin.

6201: Scpecmber 1997. TI Monctary Policy Regimes and Economic Performance: The Historical Record. dU Bordo, Michacl D.; Schwartz, Anna J.

6202: September 1997. TI Chinese Rural Industrial Productivity and Urban Spillovers. AU Peng, Yusheng; Zucker, Lynne G.; Darby, Michael R.

6203; Scptember 1997. TI Verical Multinationals and Host-Country Charactcristics. AU Zhang, Kevin H.; Markusen. James R.

6204: September 1997. TI Stronger Protection or Tcchnological Revolution: What is Bchind the Recent Surge in Palenting? AU Kortum, Samuel; Lemer, Josh.

6205; October 1997. TI Foreign Direct Investment and Employment: Home Country Experience in the United States and Sweden. $\Lambda \mathbf{U}$ Blomstrom, Magnus; Fors, Gunnar; Lipsey, Robert E.

6206; October 1997. TI Trends in the Well-Being of American Women, 1970-1995. $\Lambda \mathrm{U}$ Blau, Francine D.

\section{Universite Catholique de Louvain CORE Discussion Paper}

9751: July 1997. TI Walras-Keynes Equilibria Coordination and Macroeconomics. AU Dreze, Jacques $\mathrm{H}$.

9752; July 1997. TI Cooperation vs. Free Riding in International Environmental Affairs: Two Approaches. AU Tulkens, Henry.

9753; August 1997. TI Competition in MultiCharacteristics Spaces: Hotelling was Almost Right. AU Irmen, Andreas; Thisse, Jacques-Francois.

9754; August 1997. TI Tax Harmonisation and Political Competition. AU Grazzini, Lisa: Van Ypersele. Tanguy.

9755; August 1997. TI Workers' Skills, Product Quality, and Industry Equilibrium. AU Gabszewicz, Jean J.; Turrini, Alessandro.
9756; August 1997. TI Vertically Differentiated Goods and Labour Markets. A Note on Quality, Quantity and Welfare. AU Turrini, Alessandro.

9757; August 1997. TI Robustness of the Coordinating Role of a Redundant Security. AU Hara, Chiaki.

9758; August 1997. TI The Coordinating Role of a Redundant Security in Frictional Markets. AU Hara, Chiaki.

9759; August 1997. TI Bayesian Option Pricing Using Asymmetric GARCH. AU Bauwens, Luc; Lubrano, Michel.

9760; August 1997. TI Do We Need a Power Exchange If There are Enough Power Marketers? AU Smeers, Yves; Jing-Yuan, Wei.

9761; August 1997. TI Computable Equilibrium Models and the Restructuring of the European Electricity and Gas Markets. AU Smeers, Yves.

9762; August 1997. TI Some Problems with the Ferrier/Hirschberg Bootstrap Idea. AU Simar, Leopold; Wilson, Paul W.

9763: September 1997. TI A Welfarist Version of Harsanyi's Aggregation Theorem. AU d'Aspremont, Claude; Mongin, Philippe.

9764; September 1997. TI A Linear Programming Approach to Stability, Optimization and Performance Analysis for Markovian Multiclass Queueing Networks. AU Glaycbronk, Kevin; Mora, Josc Nino.

9765; September 1997. TI Niche Search: An Application to the Manhattan Newspaper Problem. $\Lambda U$ Pedroso. Joao Pcdro.

9766: September 1997. TI Cournut-Nash Equilibria in Limit Exchange Economies with Completc Markets: A Comparison Between Two Models. AU Codognato. Giulio.

9767; September 1997. TI Homogeneous Analytic, Center Cutting Plane Mcthods for Convex Problems and Variational Inequalities. AU Nesterov, Yurii; Vial, JeanPhilippe.

9768: September 1997. TI Exact Geometry of Explosive Autoaggressive Models. $\mathbf{\Lambda} \mathrm{U}$ Van Garderen, Kees Jan.

9769: Scptember 1997. TI Endogenous Business Cycles: Capital-Labor Substitution and Liquidity Constraint with Increasing Returns to Scale. AU Bosi, Stefano; Magris, Francesco.

9770; September 1997. TI Redistribution with Unobservable Bequests: A Case for Taxing Capital Income. AU Boadway, Robin; Marchand, Maurice; Pestieau, Pierre.

9771; September 1997. TI Subsidies Versus Public Provision of Private Goods as Instruments for Redistribution. AU Boadway, Robin; Marchand, Maurice; Sato, Motohiro.

9772; October 1997. TI Efficiency Wages, Labor Heterogeneity and the Financing of the Training Cost. AU Wauthy, Xavier; Zenou, Yves.

9773; October 1997. TI Contestability and the Indeterminacy of Free Entry Equilibria. AU d'Aspremont, Claude; Dos Santos Ferreira, Rodolphe; Gerard-Varet, LouisAndre.

9774; October 1997. TI Loss Aversion Equilibrium. AU Shalev, Jonathan. 
9775; October 1997. TI Nonparametric Methods and Option Pricing. AU Ghysels, Eric; Patilea, Valentin; Renault, Eric; Torres, Olivier.

9776; October 1997. TI Continuously Updated Extremum Estimators. AU Patilea, Valentin; Renaul, Eric.

9777; October 1997. TI Auctioning Public Goods to Groups of Agents. AU Alboth, Dirk; Lemer, Anat; Shalev, Jonathan.

9778; October 1997. TI bc-opt: A Branch-and-Cut Code For Mixed Integer Programs. AU Cordier, Cecile; Marchand, Hugues; Laundy, Richard; Wolsey, Laurence A.

9779; October 1997. TI Second Order PseudoMaximum Likelihood Estimation and Conditional Variance Misspecification. AU Lejeune, Bemard.

9780; October 1997. TI Modelling Interest Rates with a Cointegrated VAR-GARCH Model. AU Bauwens, Luc; Deprins, Dominique; Vandeuren, Jean-Pierre.

9781; October 1997. TI A Bayesian Approach to Dynamic Tobit Models. AU Wei, Steven X.

9782; October 1997. TI Export Restraints and Horizontal Product Differentiation. AU Boccard, Nicolas; Wauthy, Xavier.

9783; November 1997. TI The Hotelling Model with Capacity Precommitment. AU Boccard. Nicolas; Wauthy, Xavier.

9784; November 1997. TI Privatizing Social Security: A Critical Assessment. AU Belan, Pascal; Pcsticau, Pierrc.

9785; November 1997. TI Economics Integration as a Partition Function Game. AU Morelli, Massimo; Penelle, Philippe.

9786; November 1997. TI Redistributive Taxation and Migration Under Uncertainty. AU Leite-Monteiro, Manuel.

9787; November 1997. TI Capital-Labor Substitution and Competitive Nonlinear Endogenous Business Cycles. AU Grandmont, Jean-Michel; Pintus, Patrick; De Vilder, Robin.

9788; November 1997. TI Expectations Formation and Stability of Large Socioeconomic Systems. AU Grandmont, Jean-Michel.

9789; November 1997. TI The Logarithmic ACD Model: An Application to Market Microstructure and NASDAQ. AU Bauwens, Luc; Giot, Pierre.

9790; December 1997. TI Subscription as a Price Discrimination Device. AU Gabszewica, Jean J.; Sonnac, Nathalie.

9791; December 1997. TI Comparison of Information Structures. AU Gossner, Olivier.

9792; December 1997. TI Secure Protocols or How Communication Generates Correlation. AU Gossner, Olivier.

9801; January 1998. TI Two-Dimensional Gantt Charts and a Scheduling Algorithm of Lawler. AU Goemans, Michel X.; Williamson, David P.

9802; January 1998. TI Managers Compensation and Collusive Behaviour Under Cournot Oligopoly. AU Marini, Marco.

9803; January 1998. TI The Consequences of Overlapping Tax Bases for Redistribution and Public Spending in a Federation. AU Boadway, Robin; Marchand, Maurice; Vigneault, Marianne.

9804; January 1998. TI Optimal Tax Mix with Merit Goods. AU Del Mar Racionero, Maria.

9805; January 1998. TI Cash-in-Advance Constraints in the Diamond Overlapping Generations Model: Neutrality and Optimality of Monetary Policies. AU Crettez, Bertrand; Michel, Philippe; Wigniolle, Bertrand.

9806; January 1998. TI Non-Linear Taxation of Bequests, Equal Sharing Rules and the Tradeoff Between Intraand Inter-Family Inequalities Optimality. AU Cremer, Helmuth; Pestieau, Pierre.

9807; January 1998. TI Liquidity Constraints and Cycles. AU Rochon, Celine.

9808; January 1998. TI A Parallel Interior-Point Algorithm for Linear Programming on a Shared Memory Machine. AU Andersen, Erling D.; Andersen, Knud D.

9809; January 1998. TI On a Three Way Equivalence.

AU Koutsougeras, Leonidas C.

9810; January 1998. TI Unique Implementation in Auctions and in Public Goods Problems. AU d'Aspremont, Claude; Cremer, Jacques; Gerard-Varct, Louis-Andre.

9811; January 1998. TI Mixing Mixed-Intcger Inequalities. AU Gunluck, Oklay; Pochet, Yves.

9812; February 1998. TI Economic Dynastics with Intermissions. $\mathbf{A U}$ Gevers, Louis; Michel, Philippe.

9813; February 1998. TI Sunspot Equilibria Out of the Stable Manifold. $\mathbf{U}$ Bloisc, Gactano.

9814; February 1998. TI Loss Aversion in Repeated Gamcs. AU Shalev, Jonathan.

9815: February 1998. TI A Censored-GARCH Model of Asset Returns with Price Limits. $\mathbf{\Lambda U}$ Wei, Steven X.

9816; February 1998. TI Bid-Ask Price Compctition with Asymmetric Information Between Market Markers. AU Calcagno, Riccardo; Lovo, Stefano M.

9817; February 1998. TI Profit Maximizing in Auctions of Public Goods. AU Alboth, Dirk; Lemer, Anat; Shalev, Jonathan.

9818; January 1998. TI Import Restraints and Quality Choice Under Vertical Differentiation. AU Boccard, Nicolas; Wauthy, Xavier.

9819; March 1998. TI Heterogencous Probabilities in Complete Asset Markets. AU Calvet, Laurent; Grandmont. Jean-Michel; Lemaire, Isabelle.

9820; March 1998. TI Voluntary Contributions with Uncertainty: The Environmental Quality. $\mathrm{UU}$ Jouvet, Pierre-Andre.

9821; April 1998. TI Parabolic Target Space and Primal-Dual Interior-Point Methods. AU Nesterov, Yurii.

9822; April 1998. TI Voting for Voters: A Model of Electoral Evolution. AU Barbera, Salvadore; Maschler, Michael; Shalev, Jonathan.

9823; April 1998. Tr Strategic Learning in Games with Symmetric Information. AU Gossner, Olivier; Vielle, Nicolas.

9824; April 1998. TI Bayesian Identification of Semi-Parametric Binary Response Models. AU Mouchar, Michel; Rolin, Jean-Marie; Scheihing, Eliana. 
9825; April 1998. TI Identification Problems in a Class of Mixture Models with an Application to the LISREL Modcl. AU Mouchar, Michel; San Martin, Emesto.

9826: April 1998. TI Bayesian Evaluation of a SemiParametric Binary Response Model. AU Mouchart, Michel; Scheihing, Eliana.

9827; April 1998. TI Bayesian Evaluation of NonAdmissible Conditioning: The Casc of Fisher Test. AU Mouchart, Michel; Scheihing, Eliana.

9828; May 1998. TI Investment Decisions and Normalization with Incomplete Markets: A Remark. AU Ventura, Luigi.

9829; May 1998. Tl The Equivalence of the DekelFudenberg Iterative Procedure and Weakly Perfect Rationalizability. AU Herings, P. Jean-Jacques; Vannetelbosch, Vincent J.

9830; May 1998. TI Strategic Complements and Substitutes in Bilateral Oligopolies. AU Bloch. Francis; Ferrer, Helenc.

9831; May 1998. TI A Baycsian Approach to the Econometrics of First-Price Auctions. AU Albano, Gian Luigi: Jouncau, Fredcric.

9832; May 1998. TI Transfers to Sustain CoreTheoretic Cooperation in Intemational Stock Pollutant Control. AU Germain, Marc; Toint, Philippe; Tulkens, Henry; De Zecuw, Aart.

9833; May 1998. TI On Nash Equivalence Classes of Generic Normal Form Games. $\Lambda \mathbf{U}$ Germano, Fabrizio.

University of California, San Diego, Department of Economics Working Paper

96/25R; April 1998. TI The Effects of Ability Grouping on Student Math Achievement and Resource Allocation in Secondary Schools. $\mathbf{\Lambda} \mathbf{U}$ Betts, Julian R.; Shkolnik, Jamic L.

97/05R; January 1998. TI Gcographic Mobility, Race, and Wage Diflerentials. AU Raphael, Steven; Riker, David A.

97/15R; September 1998. TI On the Dynamics of Standards. AU Sobcl, Joel.

97/30R; April 1998. TI Correlations and Volatilities of Asynchronous Data. AU Bums, Patrick; Engle, Robert F.: Mezrich, Joseph.

98/17; July 1998. TI Manipulation of Preferences and Relative Utilitarianism. AU Sobel, Joel.

98/18; July 1998. TI Introduction to M-M Processes. AU Granger, Clive W. J.; Hyung, Namwon.

98/19; August 1998. TI Identifying the Effect of Unemployment on Crime. AU Raphael, Steven; WinterEbmer, Rudolf.

98/20; August 1998. TI Immigration Reform and the Earnings of Latino Workers: Do Employer Sanctions Cause Discrimination? AU Bansak, Cynthia; Raphael, Steven.

98/21; August 1998. TI Testing for Unit Roots with Prediction Errors. AU Sanchez, Ismael.

98/22; September 1998. TI Cognition and Behavior in Normal-Form Games: An Experimental Study. AU Costa-Gomes, Miguel; Crawford, Vincent; Broseta, Bruno.
98/23; October 1998. TI Monetizing Trade: A Tatonnement Example. AU Start, Ross M.

98/24; October 1998. TI Displaced Capital. AU Ramey, Valerie A.; Shapiro, Matthew D.

98/25; October 1998. TI Spurious Regressions with Stationary Series. AU Granger, Clive W. J.; Hyung, Namwon; Jeon, Yongil.

98/26; October 1998. TI Where the Land Meets the Sea: Integrated Sustainable Fisheries Development and Artisanal Fishing. AU Squires, Dale; Grafton, R. Quentin; Alam, Mohammed Ferdous; Omar, Ishak Haji.

98/27; November 1998. TI Macroeconomic Announcements and Volatility of Treasury Futures. AU $\mathrm{Li}$, Li; Engle, Robert F.

\section{University of California, Santa Barbara, Working Papers in Economics}

98/01; October 1997. TI The Origin of the Bank of England: A Crcdible Commitment to Sovereign Debt. AU Yang, Der-Yuan.

98/02; February 1998. TI Evolutionary Stability of Incquality Structurcs. AU Ponti, Giovanni; Seymour, Robert M.

98/03; January 1998. TI Risk Sharing in a Stochastic Overlapping Generations Economy. $\Lambda U$ Bohn. Henning.

98/04; March 1998. TI Should the Social Security Tnust Fund hold Equitics? An Intcrgencrational Welfare Analysis. AU Bohn, Henning.

98/05; March 1998. TI Will Social Security and Medicare Remain Viable as the U.S. Population is Aging? AU Bohn, Henning.

98/06; May 1998. TI Implementation, Elimination of Weakly Dominated Strategies and Evolutionary Dynanics. AU Cabrales, Antonio; Ponti, Giovanni.

98/07; May 1998. TI On Market Games When Agents Cannot Be Two Places at Once. AU Garratt, Rod; Qin, Cheng-Zhong.

98/08; May 1998. TI Modcling Foreign Exchange Markets: Stock Versus Flow. AU Pippenger, John.

98/09R; July 1998. TI The Coincidence of Collective and Individual Intcrests. AU Shapiro, Perry: Petchey, Jeffrey. 98/10; June 1998. TI Policy Hamonization in Integrated Common Factor Markets. AU Shapiro, Perry; Petchey, Jeffrey.

98/11; August 1998. TI Reform of Fee-for-Service Medicare: The Forgotten Opportunity. $\Lambda \mathrm{U}$ Frech, H. E., III

98/12; May 1998. TI The Demand for Hours of Labor: Direct Evidence From California. AU Hamermesh, Daniel S.; Trejo, Stephen J.

98/13; July 1998. TI Managed Care, Distance Traveled, and Hospital Market Definition. AU Mobley. Lee Rivers; Frech, H. E., III.

98/14; September 1998. TI Efficiency, Growth and Concentration: An Empirical Analysis of Hospital Markets. AU Frech, H. E., III; Mobley, Lee Rivers.

98/15; August 1998. TI Individual Effects and Estimation of the Motives to Remit from International Migration. AU Funkhouser, Edward.

98/16; September 1998. TI Intergenerational Progress 
of Mexican-Origin Workers in the U.S. Labor Market. AU Trejo, Stephen J.

98R/17; May 1999. TI Nonstationary Panel Data Analysis: An Overview of Some Recent Developments. AU Phillips, Peter C. B.; Moon, Hyungsik R.

98/18: September 1998. TI Linear Regression Limit Theory for Nonstationary Panel Data. AU Phillips, Peter C. B.; Moon, Hyungsik R.

98/19; October 1998. TI Energy and Depletable Resources: Economics and Policy, 1973-98. AU Kolstad, Charles D.

98/20; October 1998. TI Spliting the Baby in Two: How to Solve Solomon's Dilemma When Agents are Boundedly Rational. AU Ponti, Giovanni.

98/22; October 1998. TI Can Small Fluctuations in Investors' Subjective Preferences Induce Large Volatility in Equity Prices? AU Mehra, Rajnish; Sah, Raaj.

98/23; September 1998. TI Options for Compliance with Pollution Control Regulation: The Relationship Between Abatement Costs and Bankable Permit Prices. AU Mitchell, Glenn T.; Hunter, Gregrey W.

98/24; October 1998. TI A Note on Fully-Modified Estimation of Seemingly Unrelated Regressions Models with Integrated Regressors. AU Moon, Hyungsik R.

98/25: November 1998. TI Friends Do Matter: Strategic Uncertainty and Vertical Contractual Relations. AU Cottica, Alberto; De Propris, Lisa; Ponti, Giovanni.

98/26; December 1998. TI Social Sccurity and Demographic Uncertainty: The Risk Sharing Propertics of Altemative Policies. $\Lambda U$ Bohn, Henning.

98/27; December 1998. TI Immigrant Participation in Low-Wage Labor Markets. AU Trejo, Stcphen J.

99/01; January 1999. TI Estimation of Autoregressive Roots Near Unity Using Panel Data. AU Moon, Hyungsik R.; Phillips, Peter C. B.

99/02; February 1999. TI Stochastic Growth in Schumpeterian Dynamics. AU Sengupta, Jati K.

99/03; March 1999. TI Exclusions and Demand for Insurance: Risk Theory Seminar 1999. AU Garratt, Rod; Marshall, John M.

99/04; February 1999. TI Equity Risk, Conversion Risk, and the Demand for Insurance. AU Garratt, Rod; Marshall, John $M$.

99/05; June 1999. TI Evolution of Networks and the Diffusion of New Technology. AU Mitchell, Glenn T.

99/06; July 1999. TI Maximum Likelihood Estimation in Panels with Incidental Trends. AU Moon, Hyungsik R.; Phillips, Peter C. B.

99/07; July 1999. TI Sex and Fiscal Desire.

AU Montgomery, Robert; Stuart, Charles.

99/08; July 1999. TI Solving Infinite Horizon Growth Models with an Environmental Sector. AU Kelly, David L.; Kolstad, Charles D.

University of Copenhagen, Centre for Industrial Economics Discussion Paper

97/01; February 1997. TI One Cow, One Vote?

AU Albaek, Svend; Schultz, Christian.

97/02; February 1997. TI Competition Policy:
Publicity vs. Prohibition \& Punishment. AU Martin, Stephen. 97/03; February 1997. TI Govermment-Assited Oligopoly Coordination? A Concrete Case. AU Albaek, Svend; Mollgaard, Peter; Overgaard, Per Baltzer.

97/04; February 1997. TI On the Efficiency of Decentralized Exchange with Resale Possibilities. AU Groes, Ebbe; Torben, Tranaes.

97/05; February 1997. TI How to Cheat the Auctioneer: Collusion in Auctions when Signals are Affiliated. AU Lyk-Jensen, Peter.

97/06; February 1997. TI Selection among Mutually Exclusive Investments with Managerial Private Information and Moral Hazard. AU Ande, Rick; Bogetoft, Peter, Stark, Andrew W.

97/07; March 1997. TI Experimental Tests of Consciously Parallel Behavior in Oligopoly. AU Harstad, Ronald; Martin, Stephen; Normann, Hans-Theo.

97/08; May 1997. TI Prisoners' Dilemma in Duopoly (Super)games. AU Lambertini, Luca.

97/09; May 1997. TI Newtonian Auctionecring.

AU Sasaki, Dan.

97/10; May 1997. TI Network Structurc and Entry, in the Deregulated Airline Industry. $\mathbf{\Lambda} \mathbf{U}$ Bercchman, Joseph; Poddar, Sougata; Shy, Oz.

97/11; May 1997. TI Entry into Danish Manufacturing Industrics. AU Dilling-Hansen, Mogens; Madsen, Erik Strojer; Smith, Valdemar.

97/12; August 1997. TI Capacity and Entry Deterrence under Asymmetric Information on Demand. AU Poddar, Sougata.

97/13; July 1997. TI RJVs in Product Innovation and Cartel Stability. AU Lambertini, Luca; Poddar, Sougata; Sasaki, Dan.

97/14; June 1997. TI Standardization and the Stability of Collusion. AU Lambertini, Luca; Poddar, Sougata; Sasaki, Dan.

97/15; May 1997. TI Subsidizing R\&D-Cooperatives.

AU Hinloopen, Jeroen.

97/16; July 1997. TI Spatial Duopoly with a Reservation Price. AU Hinloopen, Jeroen: Van Marrewijk. Charles.

97/17; June 1997. TI Limit Pricing when Incumbents have Conflicting Interests. $\Lambda \mathbf{U}$ Schultz, Christian.

97/18; September 1997. TI Vertical Differentiation, Trade and Endogenous Common Standards. AU Lambcrini, Luca; Rossini, Gianpaolo.

97/19; December 1997. TI Quality Uncertainty and Informative Advertising. AU Moraga-Gonzalez, Jose Luis.

97/20; December 1997. TI Advance Production, Inventory, and Asymmetric Cournot-Nash Equilbirum. AU Poddar, Sougata; Sasaki, Dan.

97/21; December 1997. TI Strategic Quality Decisions by Heterogeneously Informed Suppliers. AU Sasaki, Dan.

97/22; December 1997. TI Firm Productivity Growth and Competition. AU Dilling-Hansen, Mogens; Eriksson, Tor; Madsen, Erik Strojer; Smith, Valdemar.

97/23; December 1997. TI Tariff Strategies and Small 
Open Economies. AU Raimondos-Moller, Pascalis; Woodland, Alan D.

98/01; February 1998. TI Product Market Competition Policy and Technological Performance. AU Martin, Stephen.

98/02; April 1998. TI On the Relative Advantage of Cooperatives. AU Albaek, Svend; Schultz, Christian. 